Јелена М. Цветановска

Национална и универзитетска библиотека

„Св. Климент Охридски”, Скопље, РС Македонија cvetanovskajelena@yahoo.com
Стручни рад

UDK 025.43:[39+121

https://doi.org/10.18485/bibliotekar.2021.63.1.6

\title{
ИЗРАДА ТЕЗАУРУСА ИЗ ЕТНОЛОГИЈЕ И АНТРОПОЛОГИЈЕ
}

Сажетак: Први део рада усмерен је на основне карактеристике тезауруса као контролисаног речника и на његов значај за индексирање грађе и претраживање информација, при чему је узет у обзир и савремени контекст. У другом делу рада предложена је методологија израде тезауруса из етнологије и антропологије на основу поделе на њихове кључне области и подобласти, и након утврђивања највишег термина у хијерархији, у раду је, у складу са међународним стандардима, представљена мрежа односа за поједине изабране дескрипторе.

Кључне речи: тезаурус, контролисани речник, етнологија и антропологија, методологија израде.

\section{Увод}

Са развојем науке и технологије расте број информација о новим достигнућима, а задатак библиотека, као документационо-информационих центара, јесте да те информације обраде и учине доступним корисницима. У том процесу посебан значај има предметна обрада докумената. ${ }^{1}$

Неопходан инструмент за прецизну, једнозначну и уједначену предметну обраду је тезаурус који олакшава претраживање информација. Из тог разлога, веће библиотеке, али и друге установе за обраду специјализованих података, улажу све интензивније напоре да израде сопствене тезаурусе из различитих научних области.

1 Зорка Чекичевска, Јелена Фиданоска, Преgметеиен ойис и кайалог̄ (Скопје: Национална и универзитетска библиотека „Св. Климент Охридски”, 2003), 15-205. 
За разлику од тезауруса из природних и примењених наука, број тезауруса из друштвених и хуманистичких наука, којима припадају и етнологија и антропологија, неупоредиво је мањи. Састављање тезауруса из ових научних области веома је сложен задатак будући да етнологија и антропологија проучавају целокупно стваралаштво човека у народној култури.

У Националној и универзитетској библиотеци „Св. Климент Охридски” у Скопљу, неспорна је потреба да се састави тезаурус из етнологије и антропологије на македонском језику, имајући у виду да база података библиотеке садржи преко 15.000 записа из свих области које покривају ове науке, а све су бројније и нове етнолошке и антрополошке публикације које треба предметно индексирати.

Анализа записа указује да је основни проблем недовољна уједначеност утврђених предметних одредница. Уједначеност је још теже постићи данас када количина информација нагло расте, па је библиотекарима тешко да прате постојеће одреднице у поступку додељивања нових.

Као што је то случај и у Народној библиотеци Србије, и у Националној и универзитетској библиотеци у Скопљу, у више случајева, предметне одреднице у предметном каталогу обухватају много шири опис од стварног садржаја у документу. Разлог томе може бити недовољна стручност библиотекара за области попут етнологије и антропологије. Овако описани садржај је правилно приказан и тачан, али се утапа у многобројне записе са идентично приказаним садржајем, што отежава претраживање по предмету. ${ }^{2}$

Приказано чињенично стање указује на неопходност да се састави тезаурус из етнологије и антропологије који би давао смернице за утврђивање нових одредница и преформулисање постојећих, тамо где је то потребно. Будући да друге македонске библиотеке углавном преузимају одреднице Националне библиотеке, постојање тезауруса допринело би уједначавању предметне обраде на територији целе земље. Осим тога, израда тезауруса из етнологије и антропологије подстакла би и израду тезауруса из других научних области, са крајњим циљем да се састави макротезаурус на македонском језику.

Овај рад је прилог методологији израде тезауруса из етнологије и антропологије, и могао би послужити као полазна тачка за његово састављање. Заснован је на теоретском познавању ових научних области и

Бојана Б. Веселиновић, „Тезаурус - контролисани речник у природним наукама”, Глас библиойеке 19, 20 (2014): 61-68. 
искуству класификатора докумената из етнологије и антропологије, а ослања се и на компаративне предлоге библиотекара из региона за израду тезауруса из других области.

\section{О тезаурусу}

Бројне су дефиниције тезауруса. По Међународном стандарду за састављање и развијање једнојезичких тезауруса (ISO 2788:1986), тезаурус је по својој структури контролисани и динамички речник семантички и генерички повезаних појмова који покривају одређено подручје знања, а по својој функцији је инструмент за терминолошку контролу. ${ }^{3}$

У Упутствима за састављање и развој једнојезичких тезауруса (Еквивалент ca ISO 2788:1986) тезаурус се дефинише као „речник контролисаног језика за индексирање, формално организован тако да су унапред утврђени појмови уочљиви и јасни". ${ }^{4}$

Међународни стандард ISO 25964-1:2011 тезаурус дефинише као „контролисани и структурни речник у коме су термини који представљају појмове организовани тако да су односи међу појмовима експлицитни...” У истом стандарду се наводи да је тезаурус водич, како за класификаторе, тако и за кориснике, за избор преферентних термина или комбинације преферентних термина који представљају одређени предмет. ${ }^{5}$ Из овога је сасвим јасно да је тезаурус намењен за индексирање грађе и претраживање по предмету. Тезаурус има кључну улогу у прецизном и доследном избору одредница и пододредница. Израдом тезауруса отвара се могућност уједначене садржинске обраде, а самим тим омогућава се лакше и брже претраживање базе података. ${ }^{6}$

Постоје разне врсте тезауруса, премда у основи могу да се поделе на микротезаурусе, који покривају одређене научне области, и макротезаурусе, који покривају укупно човеково знање. Један од најрелевантнијих

3 Anisa Podbićanin, „Prilog metodologiji izrade digitalnog tezaurusa za oblast teorije književnosti" (magistarska teza, Filozofski fakultet, Sarajevo, 2020), https://www.ff.unsa/ba/ files/zavDipl/19_20/kob/Anisa_Podbićanin.pdf (преузето 23. 2. 2021).

4 JUS-ISO: Uputstvo za sastavljanje i razvoj jednojezičkih tezaurusa (Ekvivalent za ISO 2788:1986) (Beograd: Zavod za standardizaciju, 1994), 7.

5 ISO 25964-1:2011, http://iso.org/standard/53657html (преузето 20. 2. 2021).

6 Biljana Zarić, „Predmetna klasifikacija i predmetni katalog”, BOSNIACA: časopis Nacionalne $i$ univerzitetske biblioteke Bosne i Hercegovine (2017), http://bosniaca.nub.ba/index.php/bosniaca/ article/viewFile/365/368 (преузето 23. 2. 2021). 
макротезауруса израдила је Конгресна библиотека у Вашингтону. Његове предметне одреднице, као ауторитативан извор, користе многе библиотеке у свету приликом утврђивања нових одредница.

У односу на структуру сваки тезаурус треба да садржи Увод са методологијом израде, Алфабетски индекс појмова који могу да користе све категорије корисника и Стручни (Систематски) индекс. Саставни делови оба индекса су дескриптори (преферентни термини) и недескриптори (непреферентни термини). Дескриптор, као изабрани термин, који се по правилу састоји од једне или више речи, мора бити једнозначан и једносмислен, граматички и правописно исправан. Недескриптор је синоним или квазисиноним преферентног термина који је заступљен у тезаурусу, а корисника упућује на одговарајући дескриптор. ${ }^{7}$

У тезаурусу постоје три врсте основних односа међу терминима: односи еквиваленције, хијерархијски и асоцијативни односи. Односи еквиваленције постоје између дескриптора и недескриптора као термина истог или сличног значења, а недескриптор се, одговарајућом ознаком, упућује на изабрани термин - дескриптор. Хијерархијски односи надређености и подређености се успостављају међу дескрипторима. Асоцијативни однос не може да се изрази хијерархијски него упућује корисника на друге термине, који су у некаквом саодносу са дескриптором. ${ }^{8}$ За изражавање ових односа употребљавају се ознаке предвиђене међународним стандардом. Најчешће коришћене ознаке су УЗ (употреби за) која се ставља испред недескриптора, УП (употреби) која се ставља испред дескриптора, као и ознаке ШТ (шири термин), УТ (ужи термин) и СТ (сродни термин).

Захваљујући овој мрежи, тезаурус успоставља односе међу појмовима, стављајући сваки појам у контекст и релацију са другим појмовима. Повезивање појмова омогућава сагледавање појединих научних дисциплина као целина. Релациона структура је важна у предметном језику толико да поједини тезауруси забрањују појмове ван хијерархије, односно термине који нису ни у каквој релацији са другим терминима. ${ }^{9}$

Израда тезауруса је одговоран и дуготрајан процес, у који, поред библиотекара који индексирају грађу, треба укључити и стручњаке за одређене научне области. Имајући у виду стални развој појединих наука и нову терминологију, овај процес се никада не завршава.

\footnotetext{
Podbićanin, „Prilog metodologiji...”, 17-20.

8 Podbićanin, „Prilog metodologiji...”, 22-24.

9 Веселиновић, „Тезаурус...”, 64.
} 


\section{Тезаурус данас}

Доношење нових међународних стандарда за нормативну контролу и развој информационе технологије, који омогућавају састављање и одржавање нормативних датотека, у великој мери утичу на изглед, функцију и будућност тезауруса.

У контексту стандардизације нормативних података, кључни стратешки документи које је понудила ИФЛА су: Упутства за нормативне и упутне јединице (GARE) $)^{10}$ из 1984. године, Упутства за предметне нормиране одреднице и упутне јединице (GSARE) $)^{11}$ из 1993. и Упутства за нормативне записе и упутнице (GARR) ${ }^{12}$ из 2001. године. За размену нормативних података 1991. израђен је формат UNIMARC/Нормативни подаци, који је ревидиран 2001. и 2009. године. ${ }^{13}$

Имајући у виду ове новине у библиотекарству, улогу тезауруса као контролисаног речника термина који је у функцији стандардизоване и доследне предметне обраде и претраживања по предмету, преузима нормативна датотека предметних одредница. Ова нормативна датотека садржи контролисане предметне одреднице и представља уређен предметни систем који, попут тезауруса, уважава темељна начела за израду предметних одредница и води рачуна о синтактичким и семантичким односима.

Процес формирања нормативне датотеке предметних одредница је сложен, и њему обично претходи формирање нормативне датотеке личних имена, са намером да се нормирани облици личних имена у нормативним записима користе као усвојена ауторска одредница у библиографским записима, а у перспективи и као персонална предметна одредница. ${ }^{14} \mathrm{y} \mathrm{Ma-}$ кедонији су у току прелиминарне активности за формирање нормативне базе личних имена CONOR.MK.

Формирање нормативне датотеке предметних одредница подразумева ревизију предметног каталога и верификацију постојећих и нових

10 Guidelines for Authority and Reference Entries

11 Guidelines for Subject Authority and Reference Entries

12 Guidelines for Authority Records and References

13 Тања Тасић, „Нормативна контрола и нормативне листе личних имена: успостављање нормативне датотеке личних имена у Србији", Гласник Нароgне библиоиеке Србије 14, 1 (2014/2015): 7-14, www.nb.rs/view_file.php?file_id=4781 (преузето 1. 6. 2021).

14 Бојана Веселиновић, Ивана Јашовић, „Приступна тачка, каталог и нормативна контрола", Корак библиотеке, 3/2018, https://korakbiblioteke.biblioteka-uzice.rs/wp-content/ uploads/2021/01/5.-Pristupna-tacka-pdf (преузето 1. 6. 2021). 
одредница, у складу са правилима за предметну обраду и савременим научним сазнањима и терминологијом. У овом процесу од велике помоћи било би постојање тезауруса из разних области или макротезауруса, посебно у случају када предметни каталог обилује слободно формираним одредницама. Колико је већи број преферентних термина у тезаурусу утврћен, толико ће се брже одвијати формирање и имплементирање нормативне датотеке предметних одредница.

Као и тезаурус, и нормативна датотека предметних одредница омогућује претраживање по предмету. Претраживање у нормативној датотеци одвија се по приступним тачкама. Контролисане приступне тачке (нормирани и варијантни облици), које су релевантне за претраживање по предмету су: лично име, породично име, назив корпоративног тела, наслов дела/израза, име/наслов, термини за догађаје, објекте, појмове и места и др. ${ }^{15}$ По овим и другим заједничким приступним тачкама окупља се библиотечка грађа што је крајњи циљ сваког каталога.

И свакако, једна од важних предности нормативних датотека је што њихови нормативни подаци могу постати међународно препознатљиви повезивањем у јединствени виртуелни каталог VIAF. ${ }^{16}$

\section{Израда тезауруса из етнологије и антропологије}

Приликом формулисања предлога за израду тезауруса из етнологије и антропологије, коришћена је стручна литература, македонска Национална класификација културног наслеђа, а прегледан је и већи број постојећих предметних одредница које покривају ове научне области.

Упоредо су узета у обзир и искуства повезана са израдом тезауруса из различитих области у другим земљама у региону. ${ }^{17}$ Посебно детаљно је истражен Етнографски тезаурус Америчког фолклорног друштва ${ }^{18}$ који је направљен у сарадњи са Центром за амерички народни живот при

15 Изјава о међународним каталошким начелима - Statement on International Cataloguing Principles, ifla.org/files/assets/cataloguing/icp/icp_2009-sr.pdf (преузето 5. 6. 2021).

16 VIAF - The Virtual International Authority File, https://viaf.org (преузето 5. 6. 2021).

17 Ksenija Švenda-Radeljak, „Tezaurus znanstvenog područja socijalnih djelatnosti - grana socijalna politika: prilog predmetnoj obradi", Vjesnik bibliotekara Hrvatske 57, 1/3 (2014), https://hrcak. srce.hr/142263 (преузето 23. 2. 2021); Милица Црвчанин, „Методологија израде тезауруса с посебним освртом на област ликовне уметности”, Библиотеккар 28, 1 (1976): 94-112.

18 American Folklore Society Ethnographic Thesaurus (AFCET), https://id.loc.gov/vocabulary/ ethnographicTerms (преузето 20. 2. 2021). 
Конгресној библиотеци у Вашингтону. Размотрена су и решења из етнологије и антропологије Британског архивског тезауруса ${ }^{19}$ који је састављен за потребе архивског сектора у овој земљи, а користи га и Национална библиотека Велике Британије.

Сва искуства указују да је први корак у изради сваког тезауруса одређивање граничних подручја одређене науке и њених кључних области. Као што је то већ наведено, етнологија и антропологија проучавају целокупно стваралаштво човека у народној култури, а кључне области народне културе су:

- Материјална култура

- Духовна култура

- Социјална култура

Свеобухватност народне културе јасно се сагледава у даљој подели кључних области на подобласти. Материјална култура обухвата пољопривреду, сточарство, лов, риболов, скупљање плодова, занате, типове села, народну архитектуру, алате и опрему, покућнину, храну и исхрану, народне музичке инструменте, народну ношњу, трговину, транспорт. Саставни делови духовне културе су народна филозофија, народна метрологија, народна метеорологија, народна медицина, народне обредне игре и народна драма, животни и годишњи циклус празника, обичаја и обреда, обичаји и обреди повезани са послом, народна митологија и демонологија, народна уметност (ликовна пластика обредних хлебова, резбарење у дрвету, текстилна уметност, примењено сликарство, народна књижевност, народна музика, народне игре). Социјална култура покрива породицу, род и родовске групе, сродство и терминологију сродства, сексуални живот, сеоску општину, еснафске организације, народно право. ${ }^{20}$

При подели области треба имати у виду да један етнолошки и антрополошки феномен може да покрива два или сва три аспекта народне културе, и зато је потребно утврдити који од њих је доминантан како би се правилно распоредио у тезаурусу. Неки од њих, на пример, исхрана или занати, могу се подвести и под материјалну и под духовну културу.

19 UK Archival Thesaurus (UKAT), https://ukat.aim25.com/thesaurus (преузето 20. 2. 2021).

20 Ова или слична подела заступљена је у многим уџбеницима по којима се предаје на Катедрама за етнологију и антропологију, међу којима је и Институт за етнологију и антропологију при Природно-математичком факултету у Скопљу. 
Поред поделе на материјалну, духовну и социјалну културу, за коју се залаже македонска етнолошка научна мисао, може се направити и подела на материјално и нематеријално културно наслеђе, коју користи УНЕСКО, а коју прихвата македонски Закон о заштити културног наслеђа. ${ }^{21}$ У исто време македонска Национална класификација културног наслеђ ${ }^{22}$ оперише термином етнолошки предмети за материјално културно наслеђе, а за нематеријално употребљава термин духовно културно наслеђе и у његове оквире сврстава све категорије духовне и социјалне културе називајући их фолклорним добрима.

О томе која је подела прихватљивија може се дискутовати. Дајемо предност подели коју користи наука, будући да етнологија и антропологија не проучавају само традиционално културно наслеђе и његове савремене форме, већ и сасвим нове феномене, као што су одређене супкултуре (хип-хоп, турбо-фолк) или друштвене мреже у сајбер простору.

Након дефинисања кључних области и подобласти, приступа се утврђивању највишег термина у хијерархији. У етнологији и антропологији тај термин је „народна култура” који се у македонској, а и у српској науци употребљава чешће од синонима „традиционална култура”. Из овог разлога термин „народна култура” био би дескриптор, а термин „традиционална култура" недескриптор.

Етнографски тезаурус Америчког фолклорног друштва употребљава дескриптор „folk culture”, а његови синоними (недескриптори) су „vernacular culture” и „traditional culture”. У Британском архивском тезаурусу одговарајући дескриптор je „traditional cultures”, а алтернативан термин (недескриптор) je „traditional culture”. ${ }^{23}$

Дескрипторско поље преферентног термина „народна култура” изгледало би овако:

\section{НАРОДНА КУЛТУРА (дескриптор)}

УЗ Традиционална култура (недескриптор)

УТ Материјална култура

21 Закон за заштита на културното наследство, Управа за заштита на културното наследство, https://uzkn.gov.mk/pravilnici.html (преузето 18. 2. 2021).

22 Национална класификација на културното наследство, Управа за заштита на културното наследство, https://uzkn.gov.mk/pravilnici.html (преузето 18. 2. 2021).

23 Дескриптор америчког тезауруса може да се преведе као народна култура (folk culture), као и један од његових синонима (vernacular culture), док је превод другог синонима традиционална култура. Превод дескриптора Британског тезауруса је традиционалне културе, а његовог алтернативног термина традиционална култура. 
УТ Духовна култура

УТ Социјална култура

СТ Етнологија

СТ Културна антропологија

СТ Фолклор

СТ Народни живот

Будући да сваки народ има своју културу, конкретна народна култура могла би да се индексира по имену народа уз додавање тематске пододреднице „Народна култура”, нпр. Македонци - Народна култура. Друга могућност је коришћење инверзије при формулисању одреднице која означава народну културу појединих народа, нпр. Народна култура, српска. Ови начини индексирања били би наведени у објашњењу $(\mathrm{O})$ које стоји уз дескриптор.

У оквиру кључних области народне културе мрежа односа за поједине дескрипторе изгледала би овако:

НАРОДНА АРХИТЕКТУРА

ШТ Материјална култура

УТ Кућа

УТ1 Сеоска кућа

УТ2 Градска кућа

НАРОДНА ДЕМОНОЛОГИЈА

ШТ Духовна култура

УТ Вампири

УТ Ђаволи

УТ Караконџуле

УТ Некрштена деца итд.

\section{СРОДСТВО}

ШТ Социјална култура

УТ Духовно сродство

УТ1 Кумство

УТ2 Побратимство

За изражавање свих хијерархијских односа једног појма мрежа односа може се представити и на следећи начин: 
Народна култура $\rightarrow$ Социјална култура $\rightarrow$ Сродство $\rightarrow$ Духовно сродство $\rightarrow$ Кумство

$\rightarrow$ Побратимство

По моделу Етнографског тезауруса Америчког фолклорног друштва, детаљан тезаурус за области етнологије и антропологије могли би да направе Македонско етнолошко друштво и Институт за етнологију и антропологију, у сарадњи са библиотекарима који индексирају грађу из ових области и имају увид у постојеће предметне одреднице које би се преобликовале у дескрипторе, у складу са сазнањима и терминологијом етнолошке и антрополошке науке. Утврђени преференти термини за овај микротезаурус у перспективи би се инкорпорирали у нормативну датотеку предметних одредница.

\section{Закључак}

Тезаурус је контролисани и структурни речник у којем су термини који представљају појмове стављени у контекст и релације са другим терминима. Заснован је на хијерархијским везама и асоцијативним односима у оквиру неке тематске области. Захваљујући тезаурусу, појмови који се користе постају стандардизовани и једнозначни. На тај начин постиже се доследност у предметној обради докумената и њихово успешно претраживање.

Имајући у виду његов значај, библиотеке и друге установе за индексирање грађе теже да израде сопствени тезаурус. Израда тезауруса, посебно макротезауруса, одговоран је и дуготрајан процес у који се поред библиотекара укључују и стручњаци за одређене научне области.

Састављање тезауруса из области етнологије и антропологије представља веома сложен задатак с обзиром на то да те научне области обухватају целокупно стваралаштво човека у народној култури. Као и приликом израде сваког тезауруса, полазна тачка је подела етнолошке и антрополошке науке на кључне области. Основни предмет истраживања етнологије и антропологије је народна култура коју чине материјална, духовна и социјална култура. У оквиру њих даље треба одредити најрепрезентативније појмове и сместити их у тезаурус, водећи рачуна о хијерархији и сродности. У поступку израде тезауруса треба користити и постојеће предметне одреднице, које се могу преобликовати у дескрипторе, у складу са сазнањима и терминологијом етнологије и антропологије. Закључујемо да је за израду 
квалитетног тезауруса неопходна сарадња библиотекара који индексирају грађу из ових области и имају увид у постојеће предметне одреднице, и научника који поседују теоретска сазнања из етнологије и антропологије.

Овако израђени тезаурус представљао би велику помоћ приликом формирања нормативне датотеке предметних одредница у делу који покрива етнологију и антропологију.

\section{Literatura:}

1. American Folklore Society Ethnographic Thesaurus (AFSET). Library of Congress. http://id.loc.gov/vocabulary/ethnographicTerms (preuzeto 20. 2. 2021).

2. Cvrčanin, Milica. „Metodologija izrade tezaurusa s posebnim osvrtom na oblast likovne umetnosti”. Bibliotekar 28, 1 (1976): 94-112. (na ćirilici)

3. Čekičevka, Zorka, Fidanoska, Jelena. Predmeten opis i katalog. Skopje: Nacionalna i univerzitetska biblioteka „Sv. Kliment Ohridski”, 2003. (na ćirilici)

4. Izjava o međunarodnim kataloškim načelima - Statement on International Cataloguing Principles, ifla.org/files/assets/cataloguing/icp/icp_2009-sr.pdf (preuzeto 5. 6. 2021). (na ćirilici)

5. ISO 25964-1:2011. http://iso.org/standard/53657.html (preuzeto 20. 2. 2021).

6. JUS-ISO: Uputstvo za razvoj i sastavljanje jednojezičkih tezaurusa (Ekvivalent za ISO 2788:1986). Beograd: Zavod za standardizaciju, 1994.

7. Nacionalna klasifikacija na kulturnoto nasledstvo. Uprava za zaštita na kulturnoto nasledstvo. https://www/uzkn/gov.mk/pravilnici.html (preuzeto 18. 2. 2021). (na ćirilici)

8. Podbićanin, Anisa. „Prilog metodologiji izrade digitalnog tezaurusa za oblast teorije književnosti”. Magistarska teza, Filozofski fakultet, Sarajevo, 2020. https:// www.ff.unsa.ba/files/zavDipl/19_20/kob/Anisa_Podbićanin (preuzeto 23. 2. 2020).

9. Švenda-Radeljak, Ksenija. „Tezaurus znanstvenog područja socijalnih djelatnosti grana socijalna politika: prilog predmetnoj obradi”. Vjesnik bibliotekara Hrvatske 57, 1/3 (2014), https://hrcak.srce.hr/142263 (preuzeto 23. 2. 2021).

10. UK Archival Thesaurus (UKAT). https://ukat.aim25.com/thesaurus (preuzeto 20. 2. 2021).

11. Tasić, Tanja. „Normativna kontrola i normativne liste ličnih imena u Srbiji”. Glasnik Narodne biblioteke Srbije 14, 1 (2014/2015): 7-14, www.nb.rs/view.php?file_id=4781 (preuzeto 1.6. 2021). (na ćirilici)

12. Veselinović, Bojana. „Tezaurus - kontrolisani rečnik u prirodnim naukama”. Glas biblioteke 19, 20 (2014): 61-68. (na ćirilici) 
13. Veselinović, B. Bojana i Ivana Jašović. „Pristupna tačka, katalog i normativna biblioteka", Korak biblioteke 3 (2018), https://korakbiblioteke.biblioteka-uzice.rs/wp-content/uploads/2021/01/5.- Pristupna-tocka.pdf (preuzeto 1. 6. 2021). (na ćirilici)

14. Zakon za zaštita na kulturnoto nasledstvo. Uprava za zaštita na kulturnoto nasledstvo. https://www/uzkn/gov.mk/pravilnici.html (preuzeto 18. 2. 2021). (na ćirilici)

15. Zarić, Biljana. „Predmetna klasifikacija i predmetni katalog”. BOSNIACA (2017), http://bosniaca.nub.ba/index.php/bosniaca/article/viewFile/365/368 (preuzeto 23. 2. 2021).

Jelena M. Cvetanovska

National and University Library "St. Clement Ohridski", Skopje, RN Macedonia cvetanovskajelena@yahoo.com

\section{CREATION OF ETHNOLOGY AND ANTHROPOLOGY THESAURUS}

Summary: The first part of this paper is focused on basic characteristics of the thesaurus as controlled vocabulary and its importance for subject indexing and searching information, in both traditional and contemporary contexts. In the second part of the paper, a methodology for the creation of an ethnology and anthropology thesaurus is proposed. Starting with the classification of this scientific field and after the determination of the primary term in the hierarchy, a network of relations is presented for several selected descriptors, belonging to the major fields of ethnology and anthropology.

Keywords: thesaurus, controlled vocabulary, ethnology and anthropology, creation methodology.

Примљено: 9. априла 2021.

Исправке: 28. маја 2021.

Прихваћено: 10. јуна 2021. 